\title{
MIRIS
}

A Publication of the Materials Research Society

Volume 21, Number 7 ISSN: 0883-7694 CODEN: MRSBEA

ELECTROCERAMIC THIN FILMS

PART II: DEVICE APPLICATIONS

29 Electroceramic Thin Films Part II: Device Applications

0 . Auciello and R. Ramesh, Guest Editors

33 Structure and Device Characteristics of $\mathrm{SrBi}_{2} \mathrm{Ta}_{2} \mathrm{O}_{9}$-Based Nonvolatile Random-Access Memories

J.F. Scott, F.M. Ross, C.A. Paz de Araujo, M.C. Scott, and M. Huffman

40. Degradation Mechanisms in Ferroelectric and HighPermittivity Perovskites

W.L. Warren, D. Dimos, and R.M. Waser

46 High-Permittivity Perovskite Thin Films for Dynamic Random-Access Memories

A.I. Kingon, S.K. Streiffer, C. Basceri, and S.R. Summerfelt

53 Application of Electroceramic Thin Films to Optical Waveguide Devices

D.K. Fork, F. Armani-Leplingard, and J.J. Kingston

59 Ferroelectric Thin Films in Microelectromechanical Systems Applications

D.L. Polla and L.F. Francis

\section{TECHNICAL FEATURES}

14 Film as a Composite Material

C.A. Fleischer, C.L. Bauer, D.J. Massa, and J.F. Taylor

20 Remarks on the Evolution of Materials Science W.W. Mullins

\section{IUMRS}

66 IUMRS Lectureship Recipient Balkanski Presents Seminars and Lectures in Bulgaria

\section{DEPARTMENTS}

4 Research/Researchers

10 Resources

11 Facts \& Figures

12 Washington News

13 Public Affairs Forum

32 Advertisers in This Issue

79 Education Exchange

80 Historical Note

81 Library

90 Calendar

93 Classified

96 Posterminaries

\section{MRS NEWS}

671996 MRS Spring Meeting Echoes Call of Materials Community

\section{JMR ABSTRACTS}

83 Abstracts for September 1996 Journal of Materials Research

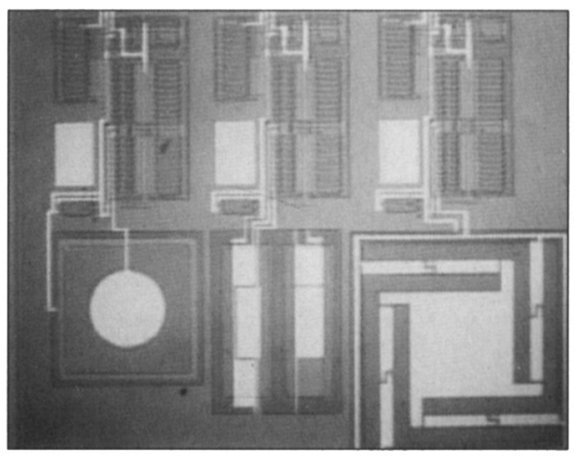

ON THE COVER: Ferroelectric thin films are being applied in a diverse range of applications, including microelectromechanical systems. Some examples are (from left to right) an acoustic sensor, a double supported microbeam accelerometer, and a tactile force sensor. For more information, see the section that begins on page 29 


\section{About the Materials Research Society}

The Materials Research Society (MRS), a nonprofit scientific association founded in 1973, promotes interdisciplinary goal-oriented basic research on materials of technological importance. Membership in the Society includes over 12,000 scientists, engineers, and research managers from industrial, government, and university research laboratories in the United States and nearly 50 countries.

The Society's interdisciplinary approach differs from that of single-discipline profes sional societies because it promotes information exchange across the many technical fields touching materials development. MRS sponsors two major international annual meetings encompassing approximately 60 topical symposia, and also sponsors numerous single-topic scientific meetings. The Society recognizes professional and technical excellence and fosters technical interaction in local geographic regions through Sections and University Chapters.

MRS participates in the international arena of materials research through the International Union of Materials Research Societies (IUMRS). MRS is a member of the Federation of Materials Societies and is an affiliate of the American Institute of Physics.

MRS publishes symposium proceedings, MRS Bulletin, Journal of Materials Research, and other publications related to current research activities.

MRS Bullotin (ISSN: 0883-7694) is published 12 times a year by the Materials Research Society, 9800 McKnight Road, Pittsburgh, PA 15237. Application to mail at second class rates has been approved at Pittsburgh, PA and at additional mailing offices. POSTMASTER: Send address changes to MRS Bulletin in care of the Materials Research Society, at the address listed; phone (412) 367-3003; fax (412) 367-4373. Printed in the U.S.A.

Additional copies of articles in MRS Bulletin may be made at $\$ 2.50$ per article. This fee can be paid to the Materials Research Society through the Copyright Clearance Center, Inc. 27 Congress Street, Salem, MA 01970.

Membership in MRS is $\$ 75$ annually for regular members, \$25 for students. Dues include an allocation of $\$ 29$ ( $\$ 17$ for students) to a subscription to MRS Bulletin. Individual member subscriptions are for personal use only. Non-member subscription rates are $\$ 135$ for one calendar year (12 issues) within the U.S.A. and $\$ 185$ elsewhere. Single copies may be purchased for $\$ 16$ each. Send subscription orders to Subscription Department, Materials Research Society, 9800 McKnight Road, Pittsburgh, PA 15237.

MRS Bulletin is included in Current Conte'nts" Engineering, Computing, and Technology; Current Contents" /Physical, Chemical, and Earth Scionces, the SciSearch ${ }^{m}$ online database, Research Alert", Science Citation Index", and the Materinls Science Citation Index". Back volumes of MRS Bulletin are available in $16 \mathrm{~mm}$ microfilm, $35 \mathrm{~mm}$ microfilm, or $105 \mathrm{~mm}$ microfiche through University Microfilms Inc., 300 North Zeeb Road, Ann Arbor, Michigan 48106.

\section{Materials Research Society 9800 McKnight Road}

Pittsburgh, PA 15237-6006

Tel. (412) 367-3003; Fax (412) 367-4373 http://www.mrs.org/

\section{MIRIS BULLETIN}

Editorial Office • 9800 McKnight Road • Pittsburgh, PA 15237-6006 Tel. (412) 367-3004 x522; fax (412) 367-4373; http://www.mrs.org/

Editor

E.L. Fleischer

Managing Editor J. Meiksin

\section{Assistant Editor}

L.R. Gallagher

Art Director

C. Love

Design/Production

T. Aiello and S. Franklin

Editorial Assistants

M.S. Cheng, J. Dininny, and

M. Wilmoth
Advertising
M.E. Kaufold
Circulation
S.E. Krasa

Guest Editors

O. Auciello and R. Ramesh

Special Contributors

C. Gilbert, D. Hosler, L.A. Krysinski,

S. McHugo, M.A. Noginov,

E. Pennisi A.M. Sherman, and R.A. Vandermeer

Special Consultant

M. Goodway
Associate Editor-Europe

I.W. Boyd

University College London

Dept. of Electronic and

Electrical Engineering

Torrington Place

London WCI E7 JE, U.K.

Tel. $44-171-380-7300$ or 7302

Book Review Editor

C.J. McHargue

University of Tennessee

Knoxville, Tennessee

MRS Office of Public Atfairs

555 13th Street NW. Suite 900 East

Washington, DC 20004

Tel. (202) 383-8809, Fax (202) 383-8877

CHAIR-EDITORIAL BOARDS

E.N. Kaufmann • Argonne National Laboratory • Argonne, Ilinois, USA

\section{INTERNATIONAL ADVISORYBOARD}

M. Balkanski

University of Pierre and Marie Curie

Paris, France

R.G. Elliman

Australian National University

Canberra, Australia

S. Hsu

Chung Shan Institute of Science

and Technology, Retired

Taiwan, China

\section{TECHNICAL EDITORIAL BOARD}

L.C. lanniello

U.S. Department of Energy, Retired

Washington, DC, USA

H-D. Li

National Science Foundation-China Beijing, China

P. Rama Rao

Ministry of Science and Technology

New Delhi, India

\section{R. Roy}

The Pennsylvania State University University Park, Pennsylvania, USA

T. Sugano

Toyo University

Tokyo, Japan

\section{J.C. Bravman}

Stanford University

Stanford, California, USA

C.W. Draper

AT\&T Engineering Research Center

Princeton, New Jersey, USA

E. Fogarassy

Centre de Recherches Nucléaires

Strasbourg, France

\section{F.Y. Fradin}

Argonne National Laboratory

Argonne, Illinois, USA

B.M. León

Universidad de Vigo

Vigo, Spain

G.L. Liedl

Purdue University

West Lafayette, Indiana, USA
S. Namba

Nagasaki Institute of Applied Science Tokyo, Japan

A.D. Romig Jr.

Sandia National Laboratories

Albuquerque, New Mexico, USA

J. Soares

Universidade de Lisboa

Lisboa, Portugal

K.C. Taylor

General Motors R\&D Center Warren, Michigan, USA

\section{MRS BULLETIN PUBLICATIONS SUBCOMMITTEE}

M. Nastasi, Chair

Los Alamos National Laboratory

Los Alamos, New Mexico

R.C. Ewing

University of New Mexico

Albuquerque. New Mexico

R.L. Fleischer

Rensselaer Polytechnic Institute

Troy, New York

\section{A.J. Hurd}

Sandia National Laboratories

Albuquerque, New Mexico

M. Libera

Stevens Institute of Technology

Hoboken, New Jersey

\section{F Shapiro}

Drexel University

Philadelphia, Pennsylvania

C.W. White

Oak Ridge National Laboratory

Oak Ridge, Tennessee

\section{MRS EXECUTIVE COMMITTEE}

\section{President}

C.V. Thompson

Massachusetts Institute of Technology

First Vice President and President-Elect

R. Hull

University of Virginia

Second Vice President and

Vice President-Elect

R.J. Nemanich

North Carolina State University

Secretary
K.S. Jones
University of Florida
Treasurer
A.K. Hays
Sandia National Laboratories
Immediate Past President
J.M. Phillips
Sandia National Laboratories

Councillors

R. Gibala

University of Michigan

A.I. Taub

Ford Research Laboratory

Executive Director

Materials Research Society

John B. Ballance

\section{INTERNATIONAL UNION OF MATERIALS RESEARCH SOCIETIES}

President

M. Doyama

Nishi-Tokyo University

Tokyo, Japan

Vice President

R.C. Ewing

University of New Mexico

Albuquerque, New Mexico USA

IUMRS ADHERING BODIES

Australian Materials Research Society (A-MRS)

J.S. Williams, Austalian National University

Chinese Materials Research Society (C-MRS)

$H-D$. Li, Tsinghua University

European Materials Research Society (E-MRS)

I.W. Boyd, University College London, UK

Materials Research Society (MRS)
Treasurer Immediate Past President

G.M. Crean

Cort, Ireland immediate

Centre de Recherches Nucléaires

Strasbourg, France
University College
General Secretary

R.P.H. Chang

Northwestern University

USA 


\section{You have to hand it}

\section{to the designers of X'Pert-MRD}
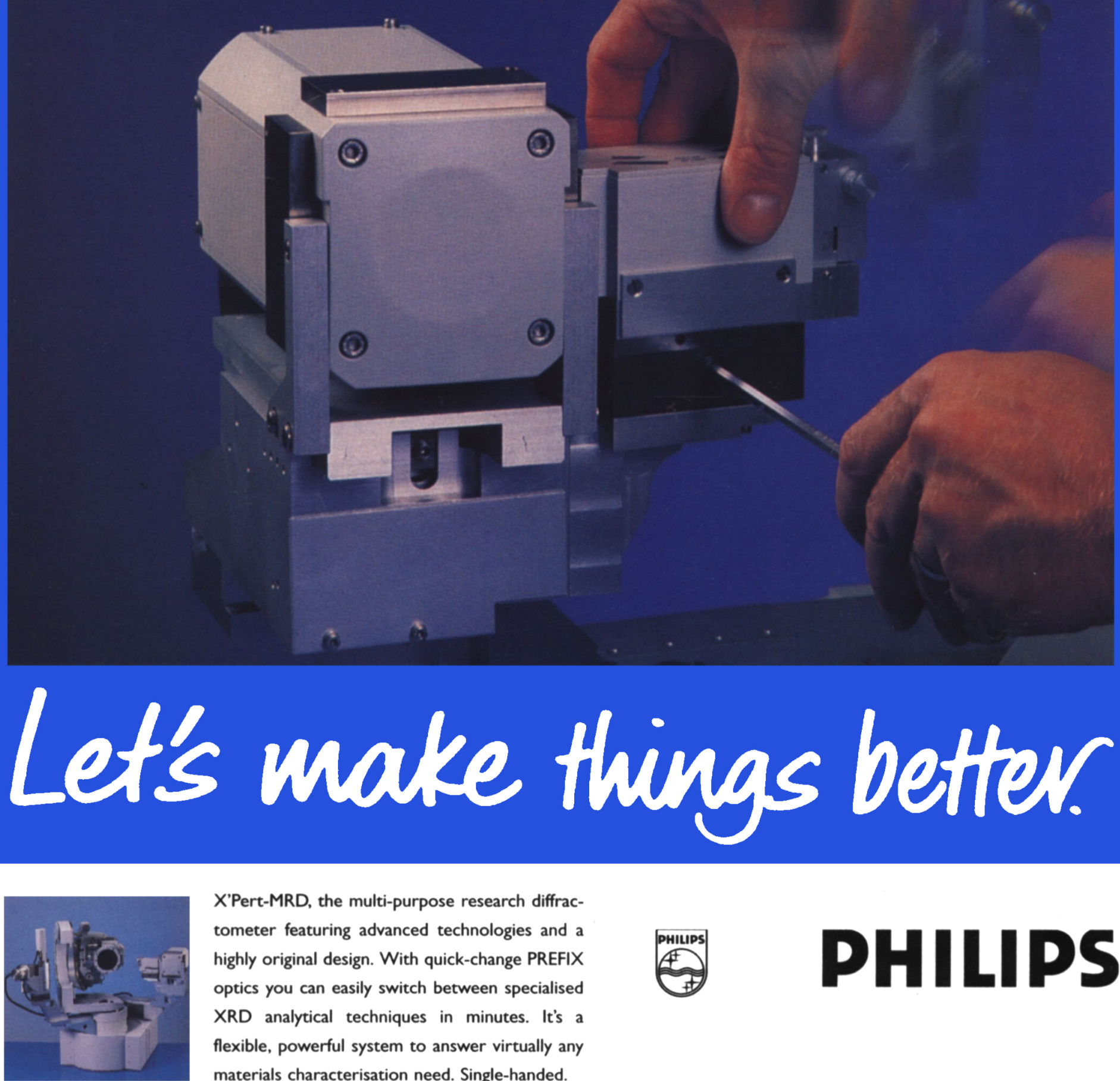

X'Pert-MRD, the multi-purpose research diffractometer featuring advanced technologies and a highly original design. With quick-change PREFIX optics you can easily switch between specialised XRD analytical techniques in minutes. It's a flexible, powerful system to answer virtually any materials characterisation need. Single-handed. 